\title{
Chapter 17 \\ Late-Life Learning in the European Union: \\ Implications for Social and Public Policy
}

\author{
Marvin Formosa
}

\section{Introduction}

This chapter puts the spotlight upon the European Union's (EU) conviction that lifelong learning holds a key role towards the achievement of a sustainable policy framework for an ageing Europe. For the EU, lifelong learning is a policy strategy that holds unlimited potential towards meeting wider economic, social and demographic challenges. More specifically, it is argued that the participation of older workers and adults in lifelong learning not only can aid senior citizens to upgrade their pension by earning extra income, but it also has the potential to contribute towards their further integration in civic society. This chapter contends that although these objectives are all positive developments towards the establishment of 'active ageing' societies, the interface between lifelong learning and later life is a more complex phenomenon. and includes social, cultural and humanistic components that cannot be overlooked.

\section{Late-Life Learning}

The reasons underlying the rising number of older adults participating in late-life learning are complex. The combination of increased longevity with a number of other social factors - ranging from improving health status, rising pensions, to more positive values and beliefs about ageing - has opened up a new phase in life, the third age, in which significant numbers of older persons spend a considerable amount of relative active years following exit from work. Indeed, the third age has engendered a period of some 15-20 years between middle age and frail old age (Laslett 1989). On its own, however, the third age does not explain why older adults became increasingly attracted to learning activities rather than choosing to spend their later years either in sheer indolence, leisure pursuits or in the company of their family circle. 
Primarily, the feminisation of ageing meant that learning programmes found an unprecedented pool of possible clients (Formosa 2005). Older women hold lower levels of educational attainment than males, and hence, it is only normal for them to be cnthusiastic about the prospect of taking part in learning activities. The fact that their houschold responsibilities decrease substantially when children leave home and husbands retire, facilitates their engagement in late-life learning. Moreover, the positive correlation of participation in secondary education with continuing learning is one of the strongest, as well as most enduring, scientific axioms of adult education. Late-life lcarning is no exception, and as each incoming cohort of older persons holds a better educational status, the yearly record levels of older adults in learning activities are far from surprising (Findsen 2005). Finally, current cohorts of older persons face a temporal kind of anxiety - that is, having a longer period of retirement on one hand, but no definite social role on the other. This sets in a tension in their daily lives, spurring feelings of uncertainty, which induces them to search for and participate in leisure activities. For Russell (2009, p. 213), "the choice of learning. . enables people in later life to actively and meaningfully participate in life", especially as they realise that their needs for self-actualisation and self-development can be met through learning. Far from simply acquiring commodities such as skills or knowledge, learning enables older persons to locate their 'authentic' self.

Despite establishing itself as the fastest growing branch of lifelong learning, latelile learning still holds a Cinderella status in official policy circles, and as such, comparative analysis of participation rates are rare (Percy and Frank 2011). Indeed, most educational statistics - including those issued by Eurostat-take the age of 65 as a cut-off point. The limited available research on participation rates (e.g. Aldridge and Tuckell 2007. 2010; Phillipson and Ogg 2010) leads to three key inferences. Firstly. that there is a negative correlation between age and levels of participation in learning with one key break' point is around the age of 55 . Secondly, that most of the opportunitics available in late-life learning are in the non-formal realm of learning avenues. And thirdly, that whilst the most popular subject is ICT, with increasing age it is 'pleasure in the act of learning', rather than 'acquiring some credential skills', that is the strongest motivation to engaging in learning. Studies note that typical older learners tend to be from dominant ethnic groups, hold a middle-class background and female; hence. suggesting that sparse efforts are invested in outreach initiatives (Formosa 2010). Another key concern in late-life learning relates to the limited learning opportunities for older people facing mobility and mental challenges, who are typically houscbound or living in residential/nursing homes. In present times, the quict older person dozing in a comfortable chair, waking up for meals and complying with the requests of carers is considered as a 'failure' rather than an efficient and sensitive model of care (Jarvis 2001). Although the link between mental fitness and good health is a slippery one and may never be unequivocally resolved, older people who continue to engage in cognitively stimulating activities have been found to be in a better position to adopt strategies assisting them to augment their well-being and independence (Mehrotra 2003). Despite damaging stereotypes, empirical studies leave no doubt that the quality of learning participation, processes and outcomes in "tourth age learning. is capable to be impressive and exceeding all expectations (Aldridge 2009). 


\section{EU Policy on Late-Life Learning}

The EU discourse on late-life learning is found as part of a comprehensive policy agenda on lifelong learning. As the EU gradually grew from an initial six countries to a 27-nation inter-governmental organisation, it became confronted with two key challenges: (1) the introduction of a new form of active citizenship that celebrates the "sharing of common values, and the development of a sense of belonging to a common social and cultural area" (European Commission (EC) 1997, p. 4) and (2), making the EU the most competitive and dynamic knowledge-based economy in the world so as to close the gap "between those who are sufficiently qualified to keep afloat in the labour market and those who are falling irrevocably by the wayside" (EC 2000 , p. 7). Faced with such a complex predicament, the concept of lifelong learning was established as the paramount solution in both policy and practice arenas. For the EU, "learning opens the door to building a satisfying and productive life" (EC 2000, p. 9). Indeed, the year 1996 was declared the European Year of Lifelong Learning, and a series of policy papers were issued by the European Commission (EC) to promulgate lifelong learning as the mantra of European public policy (EC 1995, 2000, 2001, 2006, 2007). Defining lifelong learning as "all learning activity undertaken throughout life, with the aim of improving knowledge, skills, and competences within a personal, civic, social, and/or employment-related perspective" (EC 2001, p. 9), the EU established four objectives for lifelong learning: social inclusion, active citizenship, individual development and economic productivity.

Despite the EU's fixation with lifelong, as opposed to adult learning, older persons still remained for a long time completely overlooked. It was only in Adult Learning: It is never too late to learn (EC 2006) that late-life learning was first brought at the forefront of the discussion. Herein, the EU claims that the changing demographic situation calls not only for raising the average retirement age, but also for 'active ageing' policies, which address citizens' needs during both middle age and later life. Stressing that the growing numbers of retired people in Europe are a potential source of adult educators and trainers, Adult Learning posits two objectives:

To ensure a longer working life, there is a need for up-skilling and increasing lifelong learning opportunities for older workers. It is widely acknowledged that in order to keep older workers employable, investment is needed throughout the life cycle and should be supported by government. professional bodies and sectors. Special attention should he given to those entering their mid career. [and]

An expansion of learning provision for retired people is needed (including for instance increasing participation of mature students in higher education), as people are reaching retirement in better physical and mental health. and post-retirement life expectancy is extending. Learning should be an integral part of this new phase in their lives... the Commission invited universities to "be more open to providing courses for students at a later stage of their life cycle". Such provisions will have a vital role in keeping, retired people in touch with their social environment (EC 2006, pp. 8-9).

A year later, the EU published an Action Plan on Adult Learning (EC 2007), which reiterated the need to ensure sufficient investment in the education of older people, although one notes that such an objective was strongly coupled with migrant education. Member States were called on to invest in older people and migrants, 
through education and training that matches the needs of the learner, and to raise awareness about the important role of migrants and older people in the EU. Immigration, it was affirmed, can be seen as a partial counter-balance to an aging population and skills shortages in certain sectors. In an attempt to link policy with practice, the EU coordinates the Grundtvig programme, which provides funding for projects on lifelong learning for all clients irrespective of age. The EC voices a determination to improve the quality and breadth of older adult learning, stating how "it has now become accepted that education and training have a vital role in helping older people make decisions and exercise choices about their quality of life" (EC 2010a, p. 1). Recently, Soulsby (2010) undertook a mapping exercise of known EU-funded initiatives concerned with older adult learning. Results identified some 200 networks and projects covering a range of learning activities, but mainly, inter-generational, c-learning, mentoring and volunteering.

\section{The Hegemony of Productive Ageing}

It is positive that late-life learning is no longer an overlooked area in EU policy and funding rationales. Whilst in the recent past older generations had no role to play in the strengthening of European society, as if elders were no longer needed, in current times they are frequently posited as key players in civic engagement. It is commendable that from the onset of the EU's concern for lifelong learning, citizenship has always been perceived as a major policy initiative (EC 1995). Nevertheless, a critical overview of the whole oeuvre of lifelong learning policy locates a strong link between citizenship and employability. In Towards a Europe of Knowledge, we find that the:

\footnotetext{
... citizens of Europe will be able to develop their knowledge. and this area will facilitate the enhancement of citizenship and the development of employability through the acquisition of competencies made necessary through changes in work and organisation (EC 1997. p. 2-bold in original).
}

Despite efforts in future documents to downplay the relationship between citizenship and employability. the EU's vision for lifelong learning is ultimately based on notions of human capital theory, where the key assumption is that there will be economic payoffs if a society broadens access and opportunities for lifelong learning (Borg and Mayo 2006). The economic bias that characterises the EU policies on lifelong learning implies that it is the "future worker-citizen" rather than the "democraticcitizen who is the prime asset of the social investment state" (Lister 2003, p. 433). This bias is nowhere more apparent than with respect to the role of older adults in a learning society. Indeed, the position promulgated in Adult Learning: It is never too late to learn (EC 2006) and Action Plan on Adult Learning (EC 2007) for late-life learning is unashamedly economic, where the solution to the 'ageing' problem is put as simply finding a way for older people to be economically useful. The part of the EU's discourse jars strongly with the current drive of the EU to found all Member States upon a rationale of 'active ageing' - that is: 
...the process of optimizing opportunities for health, participation and security in order to enhance quality of life as people age. [Active ageing] allows people to realize their potential for wellbeing throughout their lives and to participate in society according to their needs. desires and capabilities (EC 2010b, p. 2).

However, achieving the goals of active ageing will remain unfulfilled if discourses on lifelong learning continue to be increasingly shaped by the language of the global marketplace where learners and education are denoted as clients and a commodity, respectively. The EU vision on late-life learning never escapes the greater project to render Europe more competitive in the face of fierce competition from the transitional and multinational corporations' ability to reap the advantages of economies of scale through the expansion of international capital mobility. Evidence of this constitutes the EU's extensive drive to improve the e-learning skills of older. Although this is not in itself wrong, one has to query the EU's neglect of the whole range of abilities needed by the extensive assortment of productive sectors. Here, it is noteworthy that there is hardly any evidence to support the usefulness of a strong human capital theory for older persons (Cole 2000). Research indicates strongly that the increase of opportunities for late-life learning does not result in a surge of older persons going back into either full- or part-time employment, but only a rise in pensioners becoming increasingly active in community and civic engagement affairs (Findsen 2005). As a result, the need to help older people stay in paid work is only one priorily amongst others in late-life education. Other priorities include recognising the diversity of older persons, challenging stereotypes of ageing, maximising participation, maintaining personal independence and retaining a sense of purpose and meaning. Of course, this does not mean that policies seeking to improve the skilling of older adults should be thrown out of the window since the crucial role of productive ageing to wellbeing is well-documented (Morrow-Howell 2010), but only to underline that the vocationalisation of late-life learning will not on its own solve the future structural lag in employment or non-sustainability of pensions. So that the integration of older persons in the labour market becomes a real possibility, policies must break down barriers to labour market entry with active and preventive measures such as job search assistance, guidance and training. Late-life learning must be supplemented by measures that break down barriers between age groups in the work place, by taking a holistic approach to the needs and wishes of older workers with respect to motivation, time management and income and social protection issues. Older adults are empowered to combine partial retirement with part-time work only in so far as work remains within their capability as their life situation changes.

Another shortcoming of EU policies on lifelong learning is overlooking that when the agenda for lifelong learning is shaped primarily by market forces, older adults are frequently disadvantaged. One can never under-estimate the extent that older adults inhabit a life world typified by unique structural inequalities that limit their potential to engage in lifelong learning. As people reach the latter phases of the life course, they start experiencing ageist forms of systematic stereotyping and discrimination that embed them in a subaltern status in society - in other words, "prejudice and discrimination... based on the belief that ageing makes people less attractive, intelligent and productive" (Ferraro 1992, p. 296). Older persons whose lives are 
characterised by other lifelong 'otherisms' - such as women, the working class, ethnic minorities and gays and lesbians - face even more intense levels of exclusion and oppression since such statuses combine with ageism to produce double, and sometimes, triple jeopardise. Moreover, there can be no doubt as to the increasing probability of physical and cognitive decline with increasing birthdays, which renders older persons increasingly unable to exercise their choice to make use of the lifelong learning marketplace. Here, one cannot fail to mention that the belief that older persons in contemporary capitalism hold unprecedented levels of agency has led to the de-institutionalisation of retirement-namely, a "dismantling of welfare state provisions making work essential for many elders rather than work being the result of active choosing" (Townsend 2007, p. 21) — which is making it harder for vulnerable elders to integrate themselves fully in contemporary European society. As Phillipson (1999, p. 323) claims, the coming of late modernity did not result in the end of traditional forms of inequalities but only a "growth of new inequalities alongside the continuation of traditional social divisions". Indeed, as much as 19 $\%$ in the European Union (a total of 16 million or approximately one in five)-are living at the risk of poverty (Zaidi 20I0). Taking in consideration that productive policies are biased in favour of persons with dominant types and extensive volumes of cultural capital, what the EU offers to late-life learning is ultimately 'a model of knowledge economy for some' as opposed to 'a model of a knowledge society for all' (Healy and Slowey 2006).

The lacunae present in EU policies on late-life learning validates Perkins et al.'s (2004, p. 15) argument that valuing and championing those "population groups illsuited to the labour market calls for broader social policy goals and a recognition of other forms of contributions as well as the simple one of economic participation". Indeed, educators and policy makers need to carefully assess what they mean when laking up notions of learning and later life. Hence asking, "when we invest in lifelong education, what kind of learning is being fostered?" (Gouthro 2007, p. 145). The implication of this question for late-life learning is the subject of the coming section.

\section{Policy and Social Implications}

\section{Lifelong Learning for ALL}

Although we can celebrate the fact that life expectancy is increasing, and with it the opportunities to live an active life, it remains that some groups of older persons are at a higher risk of social exclusion. Whilst ensuring that the freedom of those who choose not to be included is not taken away, lifelong learning policy and practice has the obligation to facilitate the inclusion of older persons who, shackled by structural inequalities, are unable to participate. In listening to older persons' life histories in various empirical projects (e.g. Formosa 2000, 2005, 2007, 2009, 2010), it is clear that such persons are not the exception. It is naive to presuppose that working class elders are naturally disinclined to participate in late-life learning. Indeed, a study on 
working class elders' engagement with further and higher education demonstrated that not only is there a thirst for formal learning outside the conventional middle classes, but also that working-class elders have unlimited competence to continue to learn both within and external to the academy (Findsen and McCullough 2008). The same can be said with respect to older men and others from minority ethnic backgrounds. Golding et al.'s (2007) and Dadzie's (1993) studies are unequivocal in that if learning activities are planned and carried out in gendered and culturally sensitive ways, there is no reason to believe that one cannot have gender-balanced and multicultural learning environments. Similarly, Mott (2008) shows that if learning opportunities are made available in rural areas and are coupled with age-sensitive transport plans, a rural-urban balance in participation rates is equally feasible. $\mathrm{Fi}$ nally, the absence of homebound elders and those living in residential/nursing homes in lifelong learning is essentially the result of a relative lack of outreach and distance learning opportunities, as well as the stereotypical assumption that fourth agers have no learning interests. It is lamentable that there is no place for frail elders and carers in EU policies on lifelong learning, and to my knowledge, no Grundtvig-funded project has yet focused exclusively on fourth agers. The EU is thus called upon to: (1) advocate learning opportunities for informal family carers of older persons to enable them to focus on the dynamics of caring as well as empower the development of frail elders, and (2) call for learning sessions in residential and nursing care homes so that all older persons, even those suffering from confusion or dementia, have an opportunity to participate.

The key for a lifelong learning for ALL is to look for those class-, ethnic-, genderand ageist-specific barriers that hinder the realisation of a more democratic version of lifelong learning practice. Such barriers may range from insufficient income, language issues, biased curricula and a lack of age-friendly premises. There is also a serious need to counter the psychosocial barriers such as the stereotypical and ageist belief in the adage 'I'm too old to learn', make use of user-friendly enrolment procedures (such as low fees, appropriate venues and exciting methods of teaching and learning), and overcome communication problems such as brochures printed in too small type and crammed formatting, or a failure to display brochures in places, which older adults frequent. Achieving a lifelong learning for ALL necessitates the implementation of a 'widening participation' agenda. Policy makers and providers must work together to think out of the box so that late-life learning initiatives attract older adults who could or would not usually participate in traditional organised provision. The achievement of this objective will indeed be facilitated if central governments award local authorities a clearer role in the coordination and lead development of lifelong learning.

\section{Lifelong Learning for 'Active' Citizenship}

EU policies on late-life learning are consistent with the expectation of lengthier working careers, which would require older persons to participate in formal learning 
to update their skills. Such a standpoint, however, infuses a neo-liberal bias that equates citizenship with a 'productive' rationale as the key means for older persons to remain independent, and prove their value and worthiness. What this standpoint fails to confront is that although lifelong learning and civic engagement come across as a personal choice, preferences are often structured by social, economic and institutional factors (Ettiene and Jackson 2011). Keeping this in mind, it is warranted that lifelong learning policies embrace a broader perspective of citizenship that includes a mix of political and social rights. In other words, also calling for the right to participate in political processes and the right to live (supported by state and local authorities' services if necessary) in a civilised lifestyle according to societal standards (respectively). This will certainly not be achieved by any type of learning environment but only if educators and learners embrace a critical epistemology. Calling for attention to the triumvirate of knowledge, power and control, a critical standpoint asks fundamental questions such as: Why do we teach? Whose interests are really being served? Who controls the learning process? Why is education 'good' for people? How is quality of life enhanced by education? Educators who embed late-life learning in a critical framework (e.g. Glendenning and Battersby 1990; Formosa 2000; Findsen 2007) follow Paulo Freire's $(1972,1998)$ philosophy, which emphasises that the primary goal of education is to enable learners become in control of their thinking, and thus, be aware of their social and political rights. This is possible if educators are fully conversant with the socio-cultural context in which older adults conduct their lives. A critical epistemology for late-life learning posits educators and learners in a relationship of collaboration whereby the former do not only understand the constraints of the situation brought on by structural conditions. but are also at grips with the potential of learners to overcome oppressive practices via collective social action. It embraces a transformative rationale that not only dissects the realities surrounding older citizens, but also enables them to imagine and work together towards the realisation of a social world than is governed by life-centred values rather than the ideology of the market.

A critical stand towards late-life learning has huge potential to expand the opportunities for 'civic engagement' for those older persons who choose such a path, and wish to go beyond the traditional volunteerism that is generally expected from older generations. Most centrally, it holds much promise to lead towards higher rates of political activism, a type of activity that despite being central to citizenship has been delegitimised and relatively absent from the official agenda of civic engagement (Biggs 2001). The promotion of senior volunteerism as the only type of desirable civic involvement, whilst ignoring the value of political participation, "reinforces a trend among the citizenry to shy away from political participation and replace efforts to create systematic change upstream with one-to-one efforts downstream" (Martinson 2007. p. 63). Lifelong learning will only be successful in leading learners towards true and adequate levels of 'active' citizenship only if structural inequalities are addressed and possible alternatives proposed. 


\section{Lifelong Learning for Transcendence}

Lifelong learning is not a solely social and political phenomenon but is also closely linked to learners' psychological development. As one expects, later life is not personified by strong levels of purposefulness since the goals being reached for do not have the same existential nature as having a family, raising children or work and career. On the contrary, it is especially typified by external events that bring about and mark the transition such as children leaving the home, losing a job, taking early retirement, a divorce or death of a loved one and for women the effects of menopause (Illeris 2009). In fact, many elders participate in late-life learning because learning is experienced as important or interesting, or it has the nature of something one needs to prove to oneself and to others that she/he is still well capable of facing and overcoming cognitive challenges (Jarvis 2001). The emphasis of the EU policies on the potential of lifelong learning to lengthen working careers stands at odds with the main psychological traits in later life, especially when you consider that older individuals tend to experience "a shift in meta-perspective, from a material and rational vision to a more cosmic and transcendent one" (Tornstam 1989, p. 60). Indeed, there is a need for policies on late-life learning to address the psychological needs and interests of older persons. Moody $(1988,1990)$ argues that late-life learning must adopt a developmental perspective, which would emphasise gains as well as losses that result with the onset of ageing. Most important of all, learning environments must not let the learners forget that they are old, must tie their rich life experience in the classroom and facilitate the conversion of life experience from an obstacle into a source of strength. For Moody $(1988,1990)$, if older persons are to be educated for new roles and activities, then this must be based on an acceptance of their time limitations and taking responsibility for the well-being of generations. It is for this reason that the idea of 'leisure-time' learning is rejected since it suggests that late-life learning is not serious. One key goal of education in later life, then, lies in acknowledging learners' own finitude and death, and to strive for personal transformation - that is, transcendence. In short, transcendence learning provides the opportunity to explore learning goals that people at earlier stages of the life course are often too busy to pursue, such as contemplating the meaning of life, coming to terms with one's past as a preparation for death and the quest for self-fulfilment and spiritual advancement.

Lifelong learning for transcendence complements a lifelong learning for 'active' citizenship as both standpoints strive for transformation. However, whilst the latter takes the form of political struggle and revolutionary consciousness aimed at transforming the world, lifelong learning for transcendence is an existentialist project targeting personal transformation. Lifelong learning for transcendence highlights how later life is also a process of psychological individuation or self-realisation-that is, "returning to our origins to become the total, unified personality symbolized by the archetype of the self" (Moody 1990, p. 35). In practice, this entails learning sessions that take to task the fact that retirement remains an incomplete ritual due to the fact that society has yet to evolve ways of dealing with retirees in a purposeful manner. This is the chief priority of pre-retirement planning courses, which strive 
to make older workers aware of the key ingredients for a successful retirementnamely, health prevention, social networking, adequate housing, sufficient income and an adequate personal philosophy. Unfortunately, no mention of pre-retirement planning courses is found in EU policies on lifelong learning, and to my knowledge, there has been Grundtvig funding for this type of learning environment.

\section{Conclusion}

This chapter has indicated how the EU's vision for late-life learning includes a strong economic bias. The achievement of productive ageing is only one possible rationale for late-life learning, and only one of many components, which leads older adults to age successfully. Policy on late-life learning should consist of meaningful pursuits, which contribute towards the holistic well-being of older adults, his or her family, the local community and society at large and should not only be concerned with paid employment or production. Following Walker (2002, p. 124), "this is not to downgrade the importance of employment, which remains the leading method of inclusion, but to recognize that activity means more than paid work". This article has argued that a more socially democratic and humanist policy on late-life learning necessitates the EU to cultivate a sensitivity towards the fact that many older persons' engagement in lifelong learning is obstructed by structural barriers, ensure that late-life learning to further the participation of older adults in political activism, and finally, conduct learning programmes that in tune with the psychological development traits that tend to characterise later life.

\section{References}

Aldridge, F. (2009). Enhancing informal adult learning for adult learning in care settings: Interim report and consultation document. Leicester: NIACE.

Aldridge. F. \& Tuckett. A. (2007). What older people learn: The whys and wherefores of older people learning. Leicester: NIACE.

Aldridge. F.. \& Tuckett. A. (2010). A change for the better: The NIACE survey on adult participation in learning 2010. Leicester: NIACE.

Biggs. S. (2001). Towards a critical narrativily: Stories of ageing in contemporary social policy. Journal of Aging Studies, 15(4). 303-316.

Borg. C.. \& Mayo. P. (2006). Learning and social difference: Challenges for public education and critical pedagogy. Boulder: Paradigm Publishers.

Cole. M. $(2000)$. The issue of age in the learning age: A critical review of lifelong learning in the United Kingdom under new labour. Education and Ageing, 5(3), 437-53.

Dadzic. S. (1993). Older and wiser: A study of educational provision for black and ethmic minority. elders. Leicester: NIACE.

Ettienc. J.. \& Jackson, S. (2011). Beyond the home: Informal leaning and community participation for older women. In S. Jackson (Ed.). Innovations in lifelong learning: Critical perspectives on diversitv: participation. and vocational learning (pp. 49-66). London: Routledge.

European Commission (EC). (1995). White paper on teaching and learning. Brussels: European Commission. 
European Commission (EC). (1997). Towards a Europe of knowledge. COM (1997) 563 final. Brussels: European Commission.

European Commission (EC). (2000). A memorandum on lifelong learning. SEC (2000) 1832. Brussels: European Commission.

European Commission (EC). (2001). Making a European area of lifelong learning a reality. COM (2006) 678 final. Brussels: European Commission.

European Commission (EC). (2006). Adult learning: It is never too late to learn. COM (2006) 6/4 final. Brusscls: European Commission.

European Commission (EC). (2007). Action plan of adult learning: It is never too late to learn COM (2006) 614 final. Brussels: European Commission.

European Commission (EC). (2010a). Grundtvig. Brussels: European Commission. http://eacea.ec.europa.eu/llp/events/infodays_2010/pdi_Ipp/4_2_grundtvig_en.pdf. Accessed $12 \operatorname{Jan} 2011$.

European Commission (EC). (2010b). Decision of the European parliament and of the council on the European year for active ageing 2012. SEC (2010) 1002 final. Brussels: European Commission.

Ferraro, K.,(1992). Cohort changes in images of older adults. The Gerontologist, 32(3). 296-304.

Findsen, B. (2005). Learning later. Malabar: Krieger.

Findsen. B. (2007). Freirean philosophy and pedagogy in the adult education context: The case of older adults' learning. Studies in Philosophy and Education, 25(6), 545-559.

Findsen, B., \& McCullough, S. (2008). Older adults' engagement with further and higher education in the West of Scotland: Tracking educational journeys. Final report. Glasgow: Department of Adult \& Continuing Education. University of Glasgow \& the West of Scotland Wider Access Forum.

Formosa. M. (2000). Older adult education in a Maltese university of the third age: A critical perspective, Education and Ageing, 15(3), 315-339.

Formosa. M. (2005). Feminism and critical educational gerontology: An agenda for good practice. Ageing International, 30(4), 396-411.

Formosa, M. (2007). A Bourdieusian interpretation of the university of the third age in Malta. Journal of Maltese Education Research, 4(2), 1-16.

Formosa, M. (2009). Class dynamics in later life: Older persons, class identity and class action. Hamburg: Lit Verlag.

Formosa. M. (2010). Older adult learning in Malta: Towards a policy agenda. Mediterranean Journal of Educational Studies, 15(1), 61-85.

Freirc. P. (1972). Pedagogy of the oppressed. New York: Continuum.

Freire, P. (1998). Pedagogy of hope: Reliving the pedagogy of the oppressed. New York: Continuum.

Golding. B., Brown, M., Foley, M., Harvey, J., \& Gleeson, L. (2007). Men's sheds in Australia: Learning through community contexts. Adelaide: NCVER.

Gouthro. P. A. (2007). Active and inclusive citizenship for women: Democratic considerations for fostering lifelong education. International Journal of Lifelong Education, 26(2), 143-154.

Glendenning, F., \& Battersby, D. (1990). Why we need educational gerontology and education for older adults: A statement of first principles. In F. Glendenning \& K. Percy (Eds.). Ageing. education and society: Readings in educational gerontology (pp. 219-231). Kecle: Association for Educational Gerontology.

Healy, T., \& Slowey, M. (2006). Social exclusion and adult engagement in lifelong learning: Some comparative implications for European states based of Ireland Celtic Tiger experience. Compare. 36(3), 359-378.

Illeris, K. (2009). Lifelong learning as a psychological process. In P. Jarvis (Ed.). The Routledge international handbook of lifelong learning (pp. 401-410). London: Routledge.

Jarvis, P. (2001). Learning in later life: An introduction for educators and carers. London: Page.

Laslett. P. (1989). A fresh map of life: The emergence of the third age. London: Weidenfeld \& Nicholson.

Lister, R. (2003). Investing in the citizen-workers of the future: Transformations in citisenship and the state under New Labour. Social Policy and Administration, 37(5), 427-443. 
Martinson, M. (2007). Opportunities or obligations? Civic engagement and older adults. Generations, 30(4). 59-65.

Mchrotra. C. M. (2003). In defence of offering educational programs for older adults. Educational Gerontology: 29(8). 645-655.

Moody. H. R. (1988). Abundance of life: Human development policies for an aging society. New York: Colombia University Press.

Merody. H. R. (1990). Education and the life cycle: A philosophy of aging. In R. H., Sherron \& B. Lumsden (Eds.). Introduction to educational gerontology (2nd ed., pp. 23-39). Washington: Hemisphere,

Morrow-Howell. N. (201(0). Volunteering in later life: Research frontiers. Journal of Gerontology: Social Sciences. 65B(4). 461-469.

Mott. V. W. (2008). Rural education for older adults. New Directions for Adult and Continuing Education. 117, +7-57.

Percy. K.. \& Frank. F. (2011). Senior learners and the university: Aims, learning and 'research' in the third age. In S. Jackson (Ed.). Innovations in lifelong learning: Critical perspectives on diversity, participation. and vocational learning (pp. 126-141). New York: Routledge.

Perkins. D.. Nelms. L.. \& Smyth. P. (2004). Beyond neo-liberalism: The social investment state? (Social Policy Working Paper No. 3). Melbourne: The Centre for Public Policy. http://www.bsl.org.au/pdfs/heyong_neoliberalism_social_socialinvestment_state.pdf. Accessed 20 Jan 2006.

Phillipson. C. (1999). The social construction of retirement: Perspectives from critical theory and political cconomy. In M. Minkler \& C. L. Estes (Eds.), Critical gerontology: Perspectives from political and moral econom! (pp. 315-328). Amityville: Baywood.

Phillipson. C.. \& Ogg. J. (2010). Active ageing and universities: Engaging older learners. London: Universities UK.

Russell. H. (2009). Later life: A time to learn. Educational Gerontology: 34(3), 206-224.

Soulsby. J. (2010). Editorial essay: Learning in later life-projects. conferences, and examples of practice in Europe. International Journal of Education and Ageing. 2(1). 77-85.

Tornstam. L. (1989). Gero-transcendance: A meta-theoretical formulation. Aging: Clinical and Experimental Research, I(1). 55-63.

Townsend. P. (2007). Using human rights to defeat ageism: Dealing with policy-induced 'structured dependency". In M. Bernard \& T. Scharf (Eds.), Critical perspectives on ageing societies (pp. 27-44). Bristol: The Policy Press.

Walker. A. (2002). A stratcgy for active ageing. International Social Security Review, 55(1), I2I1.34.

7aidi. A. (2010). Porerty risks for older people in EU countries-An update. Austria: European Centre for Social Policy and Research. 